SHORT COMMUNICATION

\title{
Gross Morphological and Morphometrical Developmental Studies on Harderian Gland in Chicken
}

\author{
Jigyasa Rana ${ }^{1 *}$, S.B. Banubakode ${ }^{2}$, Shailesh Kumar Patel ${ }^{3}$, D.V. Patil ${ }^{4}$ and Aditya Agrawal ${ }^{5}$ \\ ${ }^{1}$ Department of Veterinary Anatomy, FVAS, RGSC, BHU, Barkachha, INDIA \\ ${ }^{2}$ Department of Veterinary Anatomy and Histology, Nagpur Veterinary College, Seminary Hills, Nagpur, INDIA \\ ${ }^{3}$ Department of Veterinary Pathology, College of Veterinary Science E A.H., Anjora, Durg, INDIA \\ ${ }^{4}$ Department of Animal Genetics and Breeding, Nagpur Veterinary College, Seminary Hills, Nagpur, INDIA \\ ${ }^{5}$ Division of Animal Biochemistry, ICAR-IVRI, Izatnagar, Bareilly, INDIA \\ "Corresponding author: J Rana; E-mail: rana.jigyasa@gmail.com
}

Received: 17 Jan., 2020

Revised: 03 Feb., 2020

Accepted: 06 Feb., 2020

\begin{abstract}
The present gross morphological and morphometrical study was conducted on the Harderian gland of chicken. A total of 32 numbers of healthy birds were procured from the Poultry Farm of Nagpur Veterinary College, MAFSU, Nagpur. The chicks were divided into 4 groups viz. 3, 10, 17, and 24 days of age with 8 chicks in each group. It was seen that the Harderian gland was found directed towards ventro-medial aspect of the eyeball in chicks and loosely attached by periorbital fascia to the underlying muscle. The average biometrical observations of left and right Harderian gland in respect of weight, length, width and area of gland were found increased with the advancement of age. Area of the gland increased on its length from $17^{\text {th }}$ day to $24^{\text {th }}$ day of age which resulted into more elongated glands.
\end{abstract}

Keywords: Gross morphological, Morphometrical, Harderian gland, Chicken

The Harderian gland is the major exocrine paraocular gland of the birds including domestic fowl. It lies in the orbit, ventral and postero-medial to the eyeball (Rana et al., 2018). It is a peripheral lympho-epithelial organ which, together with spleen, bursa of Fabricius and caecal tonsils forms a system of avian organs that determines the immunity (Fix and Arp, 1991 and Shirama et al., 1996). The Harderian gland is an important part of conjunctiva associated lymphoid tissue (CALT) (Khan et al., 2007; Pawar et al., 1998 and Payne, 1994). It presents granulocytes, macrophages, and lymphocytes in the sub-epithelial layer and lumina of the lobules for local immunity of the orbit (Baba et al., 1990; Rana et al., 2019). It is an actively secreting gland with abundance of plasma cells. The present study was aimed to investigate the age wise morphometrical development of Harderian gland in chicken.

A total of 32 numbers of healthy chickens were procured from the Poultry Farm of Nagpur Veterinary College, MAFSU, Nagpur. The birds were divided into four age groups viz. $3,10,17$, and 24 days old with 8 chicks in each group. Gross morphology and biometry of both the Harderian glands of each chick were carried out on fresh and unfixed specimens immediately after exsanguinations. The morphometrical parameters were measured for both left and right gland of each chick. Weight of the gland was measured in gm using digital weighing balance. Maximum length (in $\mathrm{cm}$ ), maximum width (in $\mathrm{cm}$ ) and area (in $\mathrm{mm}^{2}$ ) were recorded by using thread, ruler and graph paper. The mean values were calculated for left and right gland separately.

The Harderian gland was found ventral to the eyeball at 3 days of age. It was pale pink in color, hour glass

How to cite this article: Rana, J., Banubakode, S.B., Patel, S.K., Patil, D.V. and Agrawal, A. (2020). Gross morphological and morphometrical developmental studies on Harderian gland in chicken. J. Anim. Res., 10(2) 325-328 
shaped with a constriction in the middle (Fig. 1). Each gland comprised of two surfaces, two borders and two extremities. The ventral surface facing the periorbita was convex while the dorsal surface opposing, the eyeball was concave (Fig. 2).

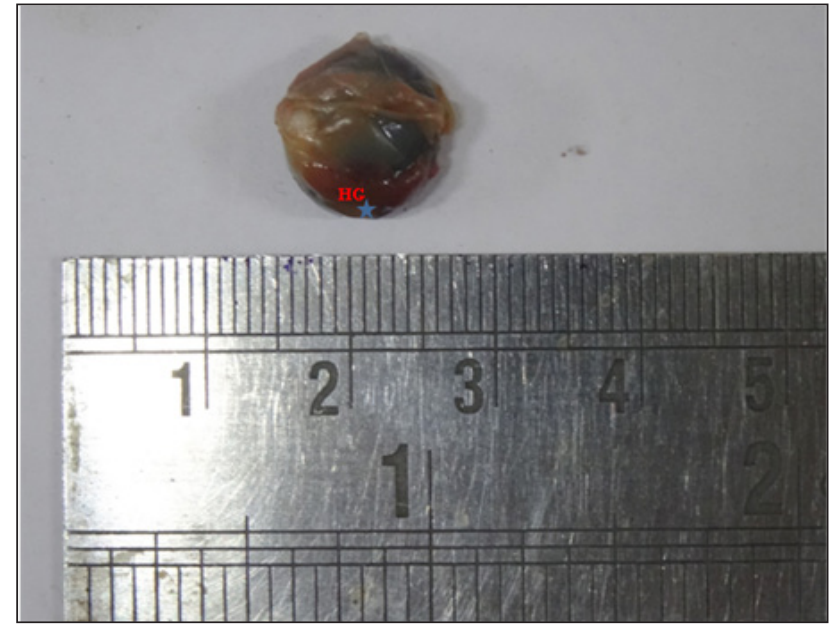

Fig. 1: Photograph of posterior part of eyeball of chicken showing Harderian gland (HG), Ventral oblique muscle ( t )

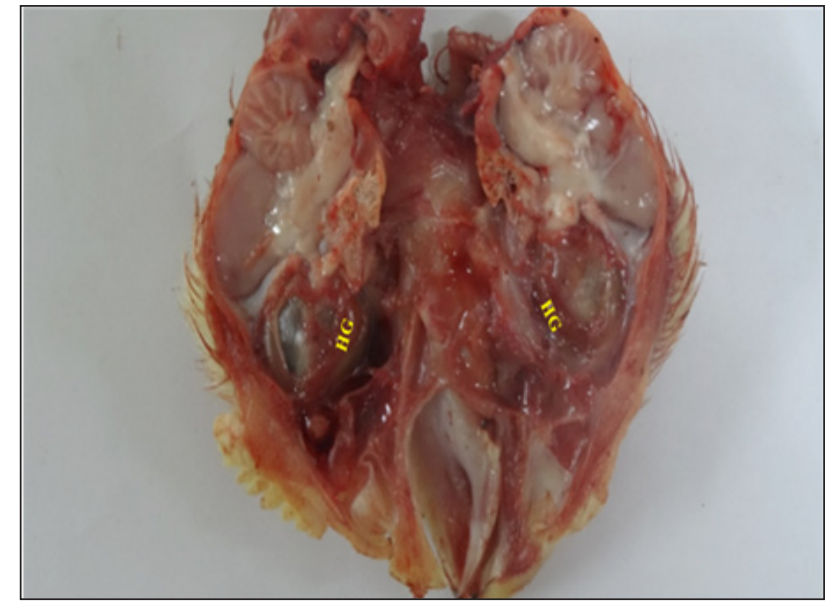

Fig. 2: Photograph of mid section of head of chicken showing ventral surface of Harderian gland (HG)

The medial border of the gland was concave and lateral border was slight convex anteriorly and concave posteriorly. The duct of the gland left the anterior extremity and opened into medial angle of the fornix of nictitating membrane. Size of the gland increased with the advancement of age (Fig. 3). These observations of the present study were in agreement with the findings of Wight et al. (1971) and Pawar et al. (2000) in domestic fowl and Onyeanusi et al. (1993) in guinea fowl as they reported similar location, color and shape of the Harderian gland as recorded in the present study.

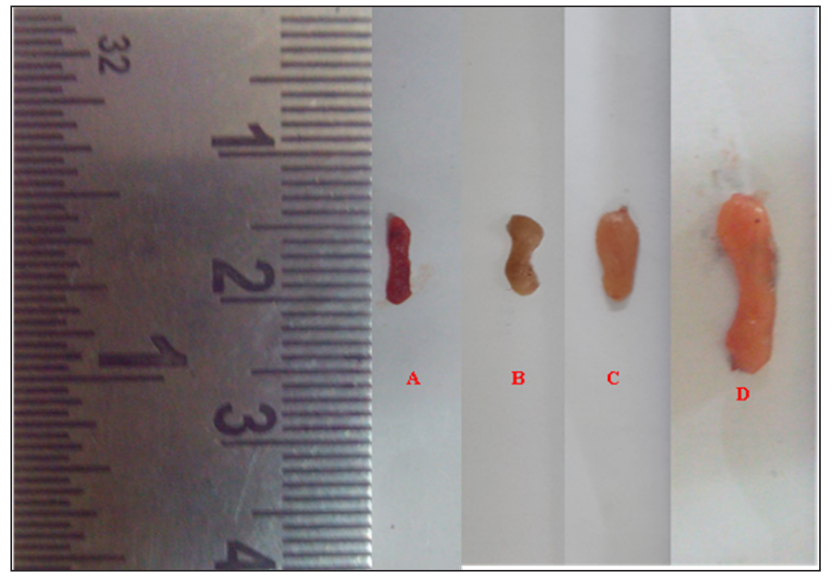

Fig. 3: Photograph showing Harderian gland at different age of chicken A. 3 day, B. 10 day, C. 17 day and D. 24 day

The average biometrical observations of left and right Harderian gland in respect of weight, length, width and area at 3, 10, 17 and 24 days of age are shown in Table 1. The measurements of weight and length showed no significant increase up to $10^{\text {th }}$ day of age but on $17^{\text {th }}$ day and $24^{\text {th }}$ day, there was significant and highly significant increase in the weight and length, respectively. Width of the gland showed no increase up to $10^{\text {th }}$ day, but at $17^{\text {th }}$ day, a significant increase in the width was recorded, which subsequently remained constant up to $24^{\text {th }}$ day, was observed. The area of both left and right Harderian gland although showed linear increase with the advancement of age from $3^{\text {rd }}$ to $17^{\text {th }}$ day of age, but the maximum increase in the area was recorded at $24^{\text {th }}$ day of age.

Observations of the present study indicated that the width of both left and right gland remained constant from $17^{\text {th }}$ day to $24^{\text {th }}$ day of age, but the area of the gland showed significant increase from $17^{\text {th }}$ day to $24^{\text {th }}$ day. Hence, it can be concluded that the area of the Harderian gland increased on its length from $17^{\text {th }}$ day onwards till $24^{\text {th }}$ day of age resulting into more elongated gland.

There was no significant difference between left and right Harderian gland with respect to any of the parameters under study which corroborated with the findings of 
Table 1: Biometrical observations showing Mean and Standard Error of weight $(\mathrm{g})$, maximum length $(\mathrm{cm})$, maximum width $(\mathrm{cm})$ and area $\left(\mathrm{mm}^{2}\right)$ of left and right ( $\left.\mathrm{L} \& \mathrm{R}\right)$ Harderian gland of Chicken of different age groups $(\mathrm{n}=8$ per group)

\begin{tabular}{llllll}
\hline \multirow{2}{*}{ Parameters } & \multicolumn{5}{c}{ Age Groups } \\
\cline { 2 - 6 } & $\mathbf{3 ~ d a y}$ & $\mathbf{1 0 ~ d a y}$ & $\mathbf{1 7}$ day & $\mathbf{2 4}$ day & CD (5\%/1\%) \\
\hline Weight (L) & $0.0113 \pm 0.0013^{\mathrm{c}}$ & $0.0175 \pm 0.0016^{\mathrm{c}}$ & $0.0338 \pm 0.0038^{\mathrm{b}}$ & $0.0475 \pm 0.0025^{\mathrm{a}}$ & $0.007 / 0.010$ \\
Weight (R) & $0.0125 \pm 0.0016^{\mathrm{c}}$ & $0.0175 \pm 0.0031^{\mathrm{c}}$ & $0.0325 \pm 0.0025^{\mathrm{b}}$ & $0.0525 \pm 0.0037^{\mathrm{a}}$ & $0.008 / 0.011$ \\
Length (L) & $0.9250 \pm 0.0164^{\mathrm{c}}$ & $0.9875 \pm 0.0398^{\mathrm{c}}$ & $1.3500 \pm 0.0378^{\mathrm{b}}$ & $1.4750 \pm 0.0491^{\mathrm{a}}$ & $0.109 / 0.147$ \\
Length (R) & $0.9875^{*} \pm 0.0227^{\mathrm{c}}$ & $1.0375 \pm 0.0800^{\mathrm{c}}$ & $1.2250 \pm 0.0453^{\mathrm{b}}$ & $1.5125 \pm 0.0441^{\mathrm{a}}$ & $0.151 / 0.204$ \\
Width (L) & $0.2438 \pm 0.0175^{\mathrm{b}}$ & $0.2125 \pm 0.0125^{\mathrm{b}}$ & $0.4625 \pm 0.0183^{\mathrm{a}}$ & $0.4750 \pm 0.0164^{\mathrm{a}}$ & $0.047 / 0.064$ \\
Width (R) & $0.2625 \pm 0.0157^{\mathrm{b}}$ & $0.2325 \pm 0.0203^{\mathrm{b}}$ & $0.4500 \pm 0.0189^{\mathrm{a}}$ & $0.4500 \pm 0.0267^{\mathrm{a}}$ & $0.060 / 0.081$ \\
Area (L) & $17.5000 \pm 1.1802^{\mathrm{d}}$ & $23.5000 \pm 0.7319^{\mathrm{c}}$ & $27.2500 \pm 1.2064^{\mathrm{b}}$ & $40.1250 \pm 1.6844^{\mathrm{a}}$ & $3.612 / 4.873$ \\
Area (R) & $16.3750 \pm 0.9246^{\mathrm{d}}$ & $25.3750 \pm 1.2809^{\mathrm{c}}$ & $30.6250^{*} \pm 0.9625^{\mathrm{b}}$ & $44.8750 \pm 2.3102^{\mathrm{a}}$ & $4.286 / 5.782$ \\
\hline
\end{tabular}

The small alphabets indicate significant difference between days and *symbol indicate significant difference between left and right side gland at $5 \%$ level.

Frahmand and Mohammadpour (2015) in ostrich and Dimitrov (2012) in common bronze turkeys. Dimitrov (2012) reported that there was 32 times increase in weight of the Harderian gland from day 1 to day 240 in common bronze turkey. He further stated that there was 3 times increase in length, 4 times increase in width and 6 times increase in circumference of the Harderian gland up to 240 days of age. These findings were in agreement with the observations recorded in the present study, where all the parameters showed increasing trend with advancement of age up to 24 days. Similarly, Banubakode et al. (2003) noted that weight, length, width and area of the Harderian gland increased with the advancement of age in broilers.

\section{CONCLUSION}

The average biometrical observation of left and right Harderian gland during the present study, in respect of weight, length, width and area of gland was increased with the advancement of age of the chicken. The area of both left and right Harderian gland increased on its length from $17^{\text {th }}$ day to $24^{\text {th }}$ day of age. There was no significant difference between left and right Harderian gland with respect to their weight, length, width and area.

\section{REFERENCES}

Baba, T., Kawata, T., Masumoto, K. and Kajikawa, T. 1990. Role of the Harderian gland in immunoglobulin-A production in chicken lacrimal fluid. Res. Vet. Sci., 49: 20-24.
Banubakode, S.B., Pavitrakar, V.N., Agrawal, V.S., Bhamburkar, V.R., Nandeshwar, N.C. and Dalvi, R.S. 2003. Age wise biometrical and histological changes in the Harderian gland of broilers. Journal of Bombay Veterinary College, 11(1 \& 2): $40-42$.

Dimitrov, D. 2012. Age-related morphometric and weight parameters of third-eyelid (Harderian) gland in common bronze turkeys (Meleagris meleagris gallopavo). Agri. Sci. Tech., 4(3): $220-222$.

Fix, A.S. and Arp, L.H. 1991. Morphologic characterization of conjunctiva associated lymphoid tissue in chicken. Am. J. Vet. Res., 52: 1852-1859.

Frahmand, S. and Mohammadpour, A.A. 2015. Harderian gland in Canadian ostrich (Struthio camelus): A morphological and histochemical study. Anat. Histol. Embryol., 44(3): 178-185.

Khan, M.Z.I., Jahan, M.R., Islam, M.N., Haque, Z., Islam, M.R. and Kon, Y. 2007. Immunoglobulin (Ig)-containing plasma cells in the Harderian gland in broiler and native chickens of Bangladesh. Tissue Cell, 39: 141-149.

Pawar, A., Venkatkrishnan, A., Vijayaragavan, C. and Ramkrishna, V. 1998. Histological study of the Harderian gland of White Leghorn with reference to plasma cells. Indian J. Anim. Sci., 68: 141-142.

Pawar, A., Venkatkrishnan, A., Vijayaragavan, C. and Ramkrishna, V. 2000. Gross morphology and biometrical study of the Harderian gland in White Leghorn birds. Indian J. Anim. Sci., 15(2): 217-219.

Payne, A.P. 1994. The Harderian gland: a tercentennial review. J. Anat., 185: 1-49.

Onyeanuasi, B.I., Ema, N.I., Ezeokoli, C.D. and Onyeanusi, J.C. 1993. The structure of the Harderian gland of the Guinea 
Fowl at embryonic and post embryonic stages. Anat. Histol. Embryol., 22: 183-190.

Rana, J., Banubakode, S.B., Nandeshwar, N.C., Charjan, Rupali and Mainde, U.P. 2018. Posthatch developmental changes in the Harderian gland of chicken. Indian J. Vet. Sci. Biotech., 13(4): 40-45.

Rana, J., Patel, S.K., Banubakode, S.B., Nandeshwar, N.C., Charjan, Rupali and Mainde, U.P. 2019. Pre-hatched developmental changes of Harderian gland in chicken. $J$. Anim. Res., 9(3): 459-464.
Shirama, K., Satoh, T., Kitamura, T. and Yamada, J. 1996. The avian Harderian gland: morphology and immunology. Microsc. Res. Techniq., 34: 16-27.

Wight, P.A.L., Burns, R.B., Rothwell, B. and Macken, G.M 1971. The Harderian gland of the domestic fowl I. Histology, with reference to the genesis of plasma cells and Russell bodies. J. Anat., 110(2): 307-315. 